\title{
Logistical, economic, environmental and regulatory conditions for future wood pellet transportation by sea to Europe: The case of Northwest Russian seaports
}

Svetlana Proskurina ${ }^{\mathrm{a}, *}$, Heli Rimppi ${ }^{\mathrm{b}}$, Jussi Heinimö ${ }^{\mathrm{c}}$, Julia Hansson ${ }^{\mathrm{d}}$, Anton Orlov ${ }^{\mathrm{e}}$, Raghu KC ${ }^{\mathrm{f}}$, Esa Vakkilainen $^{\text {a }}$

${ }^{a}$ LUT School of Energy Systems, Laboratory of Sustainable Energy Systems, Lappeenranta University of Technology, Skinnarilankatu 34, 53850 Lappeenranta, Finland

${ }^{b}$ LUT School of Energy Systems, Environmental Technology, Lappeenranta University of Technology, Skinnarilankatu 34, 53850 Lappeenranta, Finland

c Mikkeli Development Miksei Ltd, Sammonkatu 12, 50130 Mikkeli, Finland

${ }^{\mathrm{d}}$ Climate \& Sustainable Cities, IVL Swedish Environmental Research Institute, Valhallavägen 81, 10031 Stockholm, Sweden

e Institute of Forest Policy, Economics and Management, Saint Petersburg State Forest Technical University, Institutskiy per. 5, 194021 Saint Petersburg, Russia

${ }^{\mathrm{f}}$ LUT School of Energy Systems, Laboratory of Bioenergy, Lappeenranta University of Technology, Lönnrotinkatu 7, 50100 Mikkeli, Finland

*Corresponding author. Tel.: +358 466322953 .

E-mail addresses: svetlana.proskurina@lut.fi, proskurina.s@mail.ru (S. Proskurina).

Postal address: Finland, 53850 Lappeenranta, Skinnarilankatu 34.

\section{ABSTRACT}

International trade in biomass for energy is growing and wood pellets have become a very successful internationally traded bioenergy-based commodity. Russian wood pellets have captured an important share of European markets. The wood pellets are mainly transported to European markets by sea. The paper addresses challenges facing wood pellet logistics in Northwest Russia, through the ports of St. Petersburg, Vyborg, and Ust-Luga, focusing on options for seaborne transportation of pellets from producer to consumer from the economic, environmental and regulatory perspectives. The study shows that seaborne transportation of Russian wood pellets faces many constraints and without improvements in all stages of the wood pellet transportation chain through Northwest Russian seaports, the future for Russian wood pellet exports to Europe does not seem promising from the economic and environmental perspectives. Optimal logistics-related decisions require analysis of each specific situation, with detailed study of the investment and production capacities of the individual companies involved. Better knowledge of the respective stages of the wood pellet transportation chain and full consideration of the environmental aspects involved will enable effective optimization actions to be taken. This study represents a starting point for further discussion of possible improvements to seaborne wood pellet transportation to European consumers.

Keywords: Wood pellets, Seaborne transportation, Bioenergy, Russia, Environmental assessment 


\section{Abbreviations}

$\mathrm{CO}_{2} \quad$ Carbon dioxide

RBA Russian Biofuels Association

EU European Union

EU-27 Austria, Belgium, Bulgaria, Croatia, Cyprus, Czech Republic, Denmark, Finland, France, Germany, Greece, Hungary, Ireland, Italy, Latvia, Lithuania, Luxembourg, Malta, Netherlands, Poland, Portugal, Romania, Slovakia, Slovenia, Spain, Sweden, United Kingdom

FOB Free on Board

FSC Forest Stewardship Council

GHG Greenhouse gas

HELCOM The Baltic Marine Environment Protection Commission

IEA International Energy Agency

RES Renewable energy sources

$\mathrm{NO}_{\mathrm{x}} \quad$ A generic term for mono-nitrogen oxides $\mathrm{NO}$ and $\mathrm{NO}_{2}$ (nitric oxide and nitrogen dioxide)

PEFC Program for the Endorsement of Forest Certification

SFI Sustainable Forestry Initiative

UK United Kingdom

VAT Value-added tax

\section{Definitions}

\section{Biomass}

Refers to the biodegradable fraction of products, waste and residues from agricultural (including vegetal and animal substances), forestry and related industries, as well as the biodegradable fraction of industrial and municipal waste.

\section{Industrial pellets}

Refers to pellets that are produced for industrial purposes, such as heat and power production.

\section{Wood pellet}

Refers to pellets that are produced from wood. 


\section{Introduction}

International trade in biomass for energy has flourished in recent years, and wood pellets have become one of the fastest-growing internationally traded bioenergy-based commodities $[1,2,3]$. In 2006, worldwide production of wood pellets was estimated to be between approximately 6 and 7 million tons [4]. By 2012, global wood pellet production had roughly tripled and had reached 18.5 million tons [5], while the global capacity for wood pellets was estimated at 28 million tons in 2010 [6,7]. In 2014, wood pellet production increased pace, rising to 27 million tons [5]. Table 1 presents data for global trade in wood pellets. Demand for wood pellets is projected to grow, rising to 40-50 million tons by 2020 [8] and more than 50 million tons by 2025. The European Union (EU) is the main consumer of wood pellets, a position it is expected to maintain in the foreseeable future (Fig. 1).

Table 1 Global wood pellet trade in 2013, ktons, adapted from [9].

\begin{tabular}{|c|c|c|}
\hline Exporter & Importer & Volume \\
\hline Australia & EU-27 & 31 \\
\hline Belarus & EU-27 & 134 \\
\hline Bosnia and Herzegovina & EU-27 & 187 \\
\hline Canada & EU-27 & 2,093 \\
\hline Canada & Japan & 50 \\
\hline Canada & South Korea & 50 \\
\hline Canada & United States & 30 \\
\hline Croatia & EU-27 & 165 \\
\hline Egypt & EU-27 & 16 \\
\hline EU-27 & Switzerland & 39 \\
\hline EU-27 & Norway & 18 \\
\hline Norway & EU-27 & 60 \\
\hline Russia & EU-27 & 642 \\
\hline Serbia & EU-27 & 55 \\
\hline Southeast Asia(1) & Japan & 100 \\
\hline Southeast Asia(1) & South Korea & 100 \\
\hline Ukraine & EU-27 & 159 \\
\hline United States & EU-27 & 2,828 \\
\hline Other & EU-27 & 19 \\
\hline
\end{tabular}

(1) Primarily China, Malaysia, Thailand, and Vietnam. 


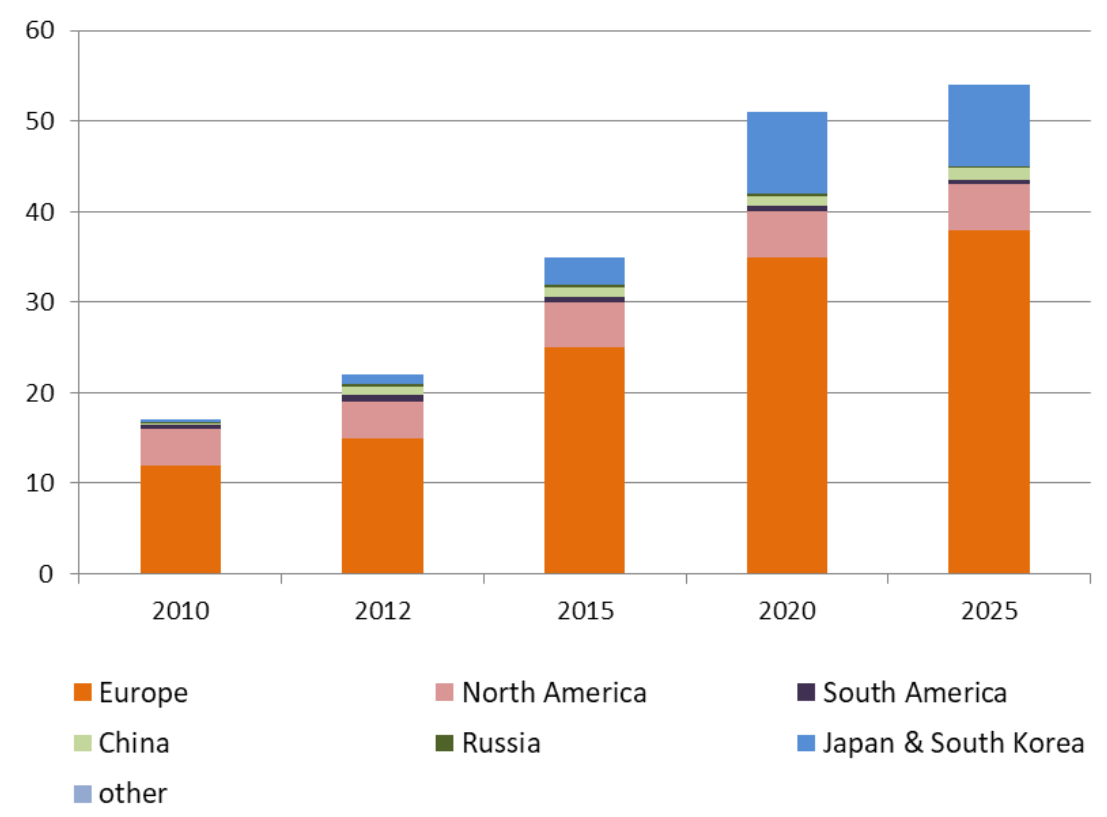

Fig. 1. Global pellet demand in millions of tons, adapted from [10].

Russian pellets have captured an important share of European markets (Table 1). Although the EU is a major producer of wood pellets [11,12], it is also a significant consumer of imported pellets [13,14] (Table 2 and Fig. 1). Russia is the world's fifth largest exporter of wood pellets after USA, Canada, Latvia, and Germany [15], and the third largest exporter of wood pellets to the EU after USA and Canada (Table 1). Principal export markets for Russian pellets are Denmark and Sweden, with Germany, Finland, and Italy comprising other important markets [16].

Wood pellets are a climate-friendly fuel compared with fossil fuels [17]. Compared with other biomass fuels, pellets are easy to handle, store and transport, and they are used as fuel for heating and electricity generation and combined heat and power. The low moisture content and relatively high heating value (about $17 \mathrm{MJ} / \mathrm{kg}$ ) of wood pellets make export to markets using long-distance transportation by ship economically attractive [18]. Mobini et al. [19] present a typical wood pellet supply chain (Fig. 2) from the source of the raw material to the end consumers. Wood pellets are usually stored in silos or warehouses, or directly bagged for distribution, and are distributed in many forms, including consumer bags $(15-18 \mathrm{~kg}$ ), big bags (500 kg), containers, railcars, and ocean vessels. In addition, residential market deliveries are performed using tank trucks, especially in Europe, where proper storage facilities are available at customers' locations [19].

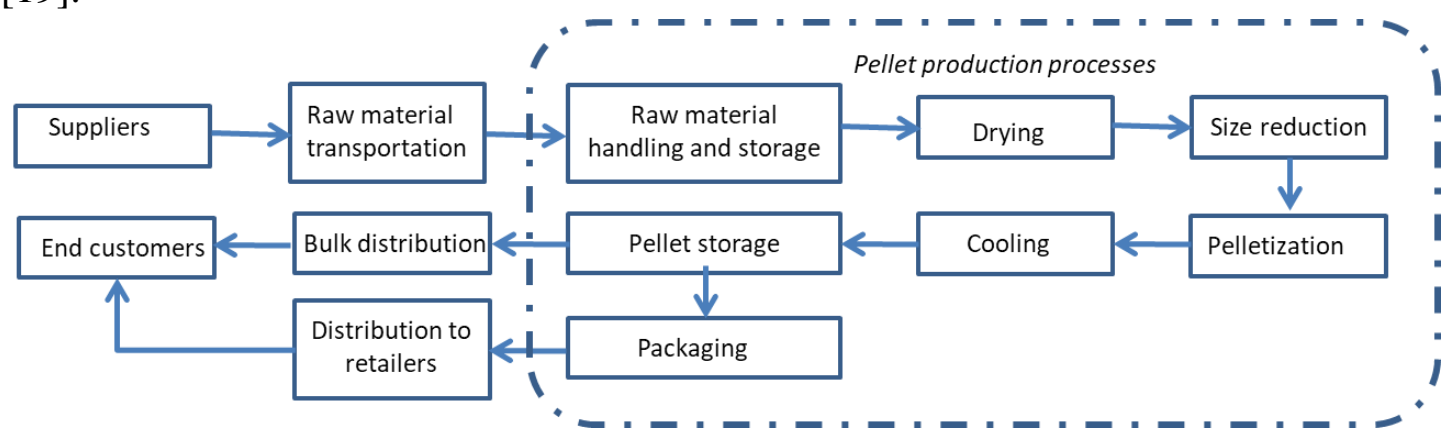

Fig. 2. Schematic of the wood pellet supply chain, adapted from [19].

Thomson et al. [20] concluded that there are a number of potential risks at all stages of the supply chain, such as environmental damage, potential price increases, and supply of inferior 
quality pellets. In describing the environmental impact of export wood pellets from Canada to Europe, Magelli et al. [21] show that improvements in the efficiency of pellet production and transportation are equally important to reducing the environmental impact associated with wood pellet production and export. Sikkema et al. [22] suggest that if pellets are produced elsewhere and transported long distances by freight train, lorries, and/or cargo ship, the environmental impact of the transportation will negate some of the environmental gains, particularly in the case of very long transport distances.

Russian wood pellets are mainly transported to European consumers by sea [23]. The largest volume of wood pellets in Northwest Russia passes through the ports of Vyborg, with approximately $50 \%$ of total seaborne wood pellet exports, and St. Petersburg and Ust-Luga, with $30 \%$ and $6 \%$ of the total seaborne wood pellet exports, respectively. Arkhangelsk and other Northwest Russian ports have a $10 \%$ and $4 \%$ share, respectively [23]. Major ports in western Russia are presented in Fig. 3. Several studies [6,19,24-26] have shown that infrastructure and logistical management are crucial to efficient wood pellet transportation, and therefore shipping costs.

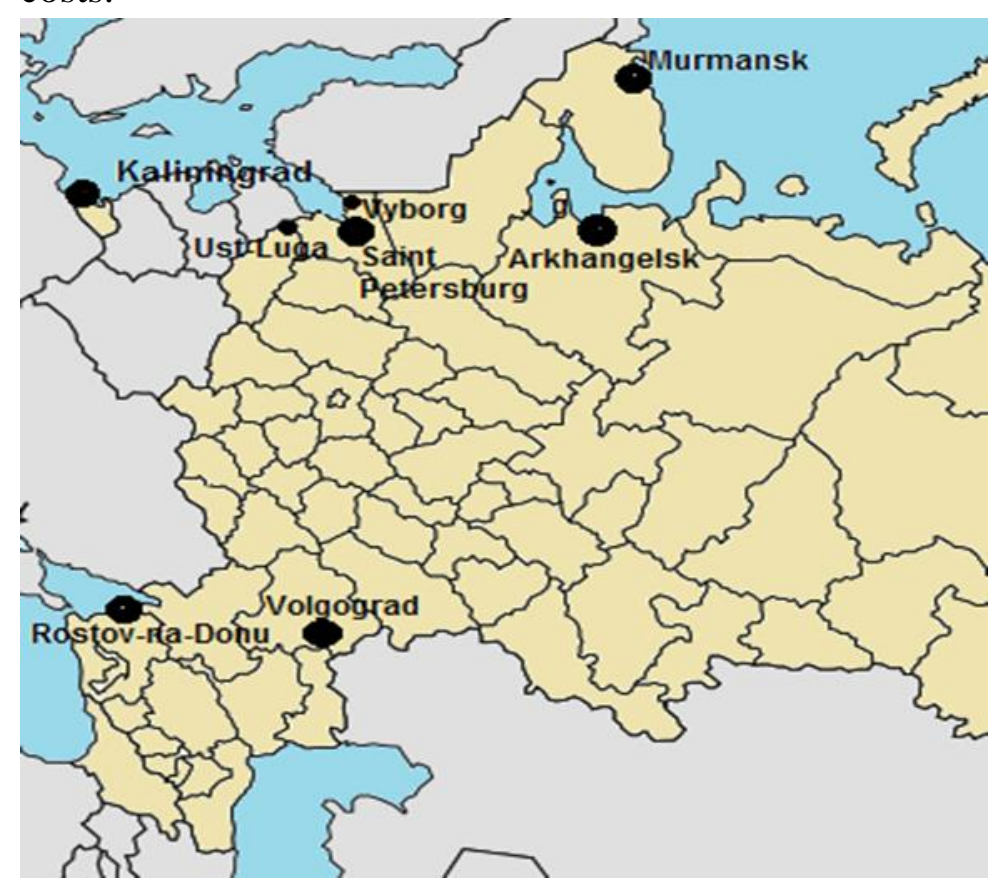

Fig. 3. Map of the main seaports in western Russia, adapted from [27].

The establishment of a both economically and logistically attractive pellet supply chain is a crucial issue in the pellet trade and current practices require improvement and development. In other words, it is necessary to focus on comprehensive optimization of the entire supply chain, from raw material acquisition and granulating lines in the plant to the large boiler furnaces in industrial installations or small boilers in private houses where the pellets are fired [25,28].

Russia is unlikely to transition from a fossil fuel based exporter to a biomass exporter. However, as a part of efforts to balance its economy, Russia has a need to diversify its exports portfolio away from too exclusive a focus on oil and gas. It should also be noted that neighboring Nordic countries have committed themselves to increasing the role of less carbon intensive primary energy sources in their primary energy production, including wood pellets. Although governments in some European countries may not wish to import biomass, as it does not decrease their dependency on imported energy [29], international trade in biomass for energy production is growing and several countries expect to import significant quantities of biomass 
also in the future (see their respective renewable energy action plans [30] and research such as $[1,31,32,33])$.

Biomass demand in the EU is expected to continue to increase as a response to policy decisions, for example, the Renewable Energy Directive [30]. In 2014, European Council [34] specified an EU-wide domestic GHG reduction target of at least 40\% below 1990 levels, an EU-wide target of at least $27 \%$ of renewables in energy consumption, and an EU-wide indicative, non-binding target of at least 27\% energy efficiency by 2030, based on 2007 projections of future consumption [35]. Scarlat et al. [31] estimate that EU domestic resources are likely to be able to provide enough raw materials to reach national targets, if intra-EU feedstock trading is included. Nevertheless, about one quarter of the EU's biomass demand in 2020 is expected to be satisfied through imports from third countries [31]. According to the World Bioenergy Association [5], in the coming years, Russia (with China) could become a major supplier of pellets to European and Asian markets.

There has been very little public discussion about Russian wood pellet export and transportation, and limited work has been presented that focuses specifically on Russian pellet transportation challenges. A general overview of bioenergy in Russia has been provided by Pristupa and Mol [36]. Aleksandrova [37] presented an analysis of the wood pellet market in Russia, in which the characteristics of the Russian wood pellet market are described and sales strategies for Russian producers suggested. Proskurina et al. [16,38] consider the main suppliers by region and discuss the European market and market restrictions in detail. It is noted that new players on the Russian pellet market face restricted opportunities, such as a lack of guaranteed access to raw materials and limited policy support [16]. Raslavičius et al. [39] consider the biomass potential in Kaliningrad Oblast. However, the authors do not discuss in detail the topic of pellet transportation, which has an important role in Russian wood pellet exports. There is currently a heightened need for further research on this question.

The objective of this research is to present an overview of Russian wood pellet sea logistics through the three most important northwestern seaports: Ust-Luga, St. Petersburg, and Vyborg. In addition, this research aims to map the conditions for future development of wood pellet transportation by sea in the northwest of Russia, focusing on the economic, environmental, and regulatory perspectives. By describing the possible transportation options at each transportation stage and EU regulations affecting Russian wood supply chain optimization, the study tries to identify related restrictions and discusses the potential future development of wood pellet transportation through Northwest Russian seaports. To our knowledge, this is the first study that reviews and combines information about port facilities and throughput, and logistical, economic, environmental conditions. Improved understanding of logistical inefficiencies will help in optimisation of the transportation chain.

Environmental aspects of wood pellet transportation, divided according to stages in the logistics chain, are also observed. At present, the most commonly discussed and studied environmental sustainability aspects of bioenergy systems are greenhouse gas balance and energy balance [40,41], including wood pellet sustainability assessments; although current approaches to sustainability assessment have been claimed to be insufficient by the scientific community (see e.g [42] and [43]) and may lead to sub-optimization of bioenergy systems. The paper focuses on the sustainability of logistics of wood pellets from Russia to the EU through Northwest Russian seaports. GHG balance and energy balance are studied and the results are presented, divided according to the stages of the supply chain, for cases where applicable information was found. In 
addition, the paper considers air pollutant emissions, which affect local air quality, especially sulphur emissions, as well as effects on the state of the Baltic Sea ecosystem and biodiversity.

The paper is structured in the following manner: Section 2 discusses wood pellet demand in Russia and current wood pellet exports to Europe. Section 3 presents current wood pellet transportation through the seaports of Ust-Luga, St. Petersburg, and Vyborg. Sections 4, 5, 6, and 7 present logistical, economic, environmental, and regulatory conditions, respectively. Section 8 discusses the main challenges and considers future perspectives. Section 9 concludes the paper.

\section{Domestic demand and export for Russian wood pellets}

Russian interest in pellet production was initiated by Western European utilities, which were looking for new pellet supplies. The first pellet production plants were set up at the beginning of 2001, in the Leningrad area. Several small producers collected pellets and delivered them by single ships to Europe. The domestic market started to develop only several years after commissioning of the first plants [16,27].

The Russian pellet industry is heavily dependent on exports. Domestic consumption data given in different Russian documents varies considerably and is often contradictory. Orlov [23] gives a figure for 2011 domestic consumption of 150,000 tons of pellets, which is about $15 \%$ of total production. Other expert estimations for 2011-2012 give about 10\% local use of total production or even less [44]. Lower-grade pellets are mainly used in domestic markets, while wood pellets that satisfy quality standards (Section 7) are mostly exported.

The Russian government has official targets for stimulating renewable energy. For instance, in 2012, the Russian government adopted "The Comprehensive Program for Development of Biotechnology in the Russian Federation through 2020" [45]. However, there are no specific targets for wood pellets, and little interest from the Russian federal government in wood pellet development $[16,44]$, only local programs for stimulation of pellet production in several regions. Thus, expectations for an increase in domestic wood pellet consumption are low in the short- and long-term perspective.

One significant economic challenge is disparity between the price of domestic pellets and the domestic oil price, which currently makes wood pellet production for the domestic market unviable [16,23]. A few large companies dominate wood pellet production in Russia and account for almost all Russian wood pellet exports. On the domestic market, the number of pellet producers is expected to decline due to the exit of small market players. In this business context, transportation becomes a crucial aspect of the Russian wood pellet industry, both for existing wood pellet production and from a long-term perspective.

As noted earlier, the EU is the main consumer of Russian pellets. The largest consumers of Russian pellets in the EU are Denmark and Sweden, where pellets are used not only by power plants but also by households and district heating plants. Despite significant domestic production in these countries, they are dependent on imports, predominantly from the Baltic region and Russia. Figure 4 shows the top five main EU consumers of Russian pellets in 2014. Other significant European consumers of Russian pellets were Latvia with 26,000 tons, The Netherlands with 25,000 tons, Estonia with 12,000 tons, Lithuania with 10,000 tons, and UK and Hungary with 7,000 tons and 3,000 tons, respectively. Several other EU countries consume smaller volumes - less than 1,000 tons of Russian pellets per year [46]. 


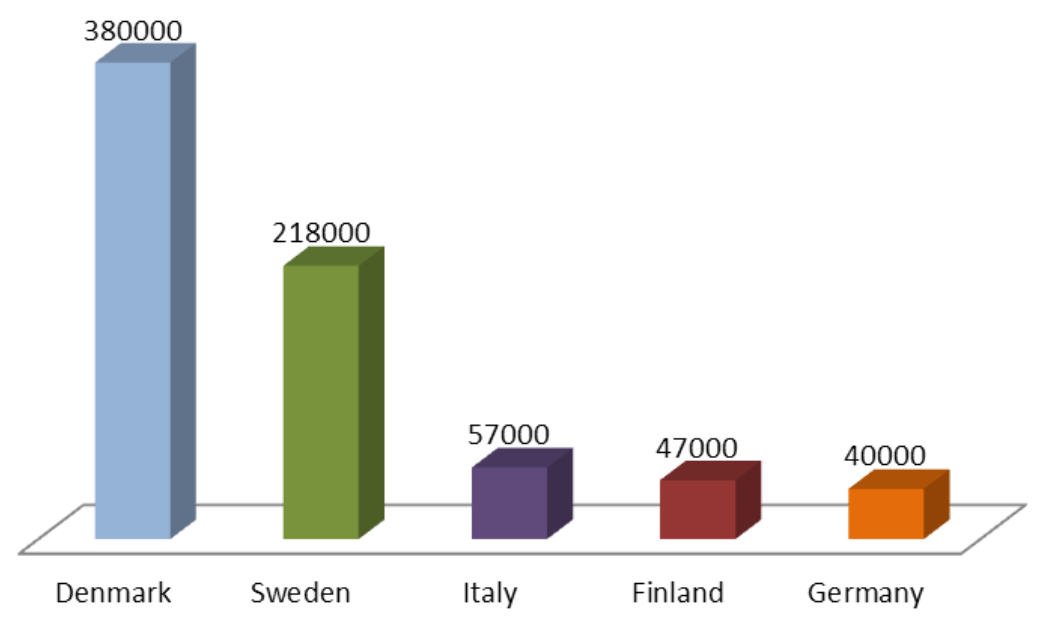

Fig. 4. Top 5 EU consumers of Russian pellets in 2014, tons, after [46].

\section{Current wood pellet transportation through selected Northwest Russian seaports}

\subsection{Vyborg}

The Port of Vyborg is located in the northeastern part of the Finnish Gulf, $113 \mathrm{~km}$ from St. Petersburg, near the Finnish border (Fig. 3). The port has a capacity of three million tons of bulk cargo and is connected with Lake Saimaa and the Finnish inland waterway system by the Saimaa Canal. Vyborg Port is equipped with equipment for handling different types of cargo (port cranes, loaders of different cargo capacity, etc.) and has a railway connection [47].

Approximately 0.8 million tons of wood pellets were exported from the Port of Vyborg to Europe in 2012 [48]. Most of the exported volume belonged to "Vyborgskaya Cellulose" (recently renamed "Vyborg Timber Corporation," "VTC") [48], which currently operates the biggest pellet production plant in Russia [49]. In addition to bulk deliveries of loose wood pellets, the port handles deliveries in big bags, with shipments of about 2,500-5,000 tons being supplied to Western European ports approximately three times per month [50].

\subsection{St. Petersburg}

Another major port for wood pellet transportation is the "Seaport of St. Petersburg," which is the largest port in the northwest of Russia [51]. In 2013 the "Seaport of Saint Petersburg" handled over 7.8 million tons of cargo [52].

Currently, the St. Petersburg port has a stable structure for wood pellet transportation. In the port of St. Petersburg, there are 3-4 suppliers/companies that organize Russian pellet vessel shipments to large industrial consumers in Western Europe. The most prominent is "Russian Biofuels Association" ("RBA"), which operates as an independent trader in the biofuel market. Another is a consortium consisting of several of the largest and most experienced pellet manufacturers operating joint export sales under long-term contracts. Companies actively involved in this consortium include companies such as "Rospolitehles" (Ust-Izhora) and "Vologdabioexport" (Great Ustyug). Since 2006 the Seaport of St. Petersburg also handles pellets acquired by several large foreign traders and energy companies [53].

Karamysheva et. al. [54], based on interviews with stakeholders in 2012-2013, concluded that the infrastructure of the "Seaport of Saint Petersburg" is not sufficiently well developed to 
provide customers with the expected level of services. For comparison, Finnish ports currently provide better services than Russian ports, according to interviews.

\subsection{Ust-Luga, Leningrad oblast}

The Port of Ust-Luga is a commercial seaport in the Northwest Federal District of Russia, Leningrad Region, approximately $100 \mathrm{~km}$ from St. Petersburg (Fig. 3). The first stage of a multicargo complex, "Yug-2" [55], was opened in 2008. The terminal capacity is 1 million tons per year, with a channel length of $4 \mathrm{~km}$ and complex length of $315 \mathrm{~m}$. The terminal has a separate railway line of $2.5 \mathrm{~km}$ to the railway station at Luzhskya. Ust-Luga owns a shunting yard and operates an outdoor storage area of 8 hectares. The period in which the port operates under ice restrictions is shorter than at other Russian ports.

Currently, the port has a project for road reconstruction. The development of the Port of UstLuga is part of a Russian federal program [56] aimed at improving the Russian transportation system, and major investments are ongoing. The project for improved pellet handling includes two stages. The first is construction by the middle of 2014 of a covered warehouse area of $1,500 \mathrm{~m}^{2}$, with a planned turnover of 60,000 tons of wood pellets per year and lump capacity of 6,000 tons of pellets. The second stage is construction by 2015 of a second warehouse to increase transshipment to 200,000 tons of pellets per year and to enable goods to be received in bulk [57].

\section{Logistical conditions}

Mobini et al. [19] present a simulation model for the design and analysis of wood pellet supply chains (Fig. 2) that can be used as a decision support tool to evaluate modifications in existing supply chains and to design new chains. This study utilizes the study by Mobini et al. [19] and focuses on the concrete case of Russian wood pellet transportation to European ports through selected seaports, addressing each part of the supply chain.

In order to study wood pellet transportation through the ports of St. Petersburg, Vyborg, and UstLuga, a simple example case of a biofuel plant located in Northwest Russia was taken. The plant plans to carry out a shipment of pellets to consumers by sea through the St. Petersburg port. A basic view of the supply chain is presented in Figure 5 .

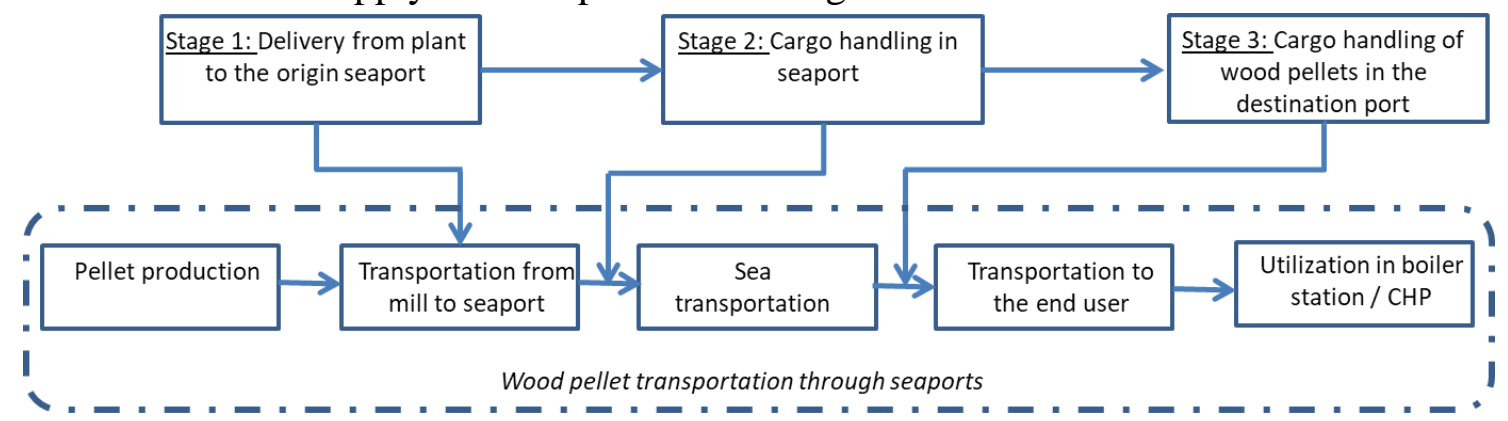

Fig. 5. Stages of wood pellet transportation by sea, after [28].

Each of the stages in the transportation of wood pellets requires careful organization. The three ports studied have differences in transportation volumes; however, the basic principles of wood pellet transportation seem similar and are applicable other ports in Russia. Section 4 presents an analysis of each stage of pellet transportation for the "Seaport of St. Petersburg". Based on that example, this study also investigates features of the ports of Vyborg and Ust-Luga. Improved 
knowledge of the stages of the wood pellet transportation chain will aid in identification of inefficiencies, thus enabling optimization actions to be taken.

\subsection{Delivery options for pellets from plant to seaport}

Most Russian pellet production plants are located near sawmills and far from seaports. Depending on the location of the wood pellet production, delivery of pellets from the production plant to the seaport can be very expensive and make the overall logistics chain expensive and uncompetitive. For long distances, land transportation can be very problematic. Currently, special delivery vehicles for wood pellet transportation (dedicated trucks and railway cars) do not exist in Russia. Additionally, several producers of wood pellets do not have direct railroad access, leading to additional loading and unloading. Table 2 presents delivery options for pellets from the case plant to the Seaport of St. Petersburg.

Table 2 Delivery options for pellets from the case plant to the Seaport of St. Petersburg (Stage 1), adapted from [28].

\begin{tabular}{|c|c|c|}
\hline Option & Features and costs & Requirements \\
\hline $\begin{array}{l}\text { Shipment in big } \\
\text { bags by road }\end{array}$ & $\begin{array}{l}\text { Cost of big bags shipment }- \text { approx. } \$ 10(\sim 8 \\
\text { euros) per ton of pellets, cost of transportation } \\
\text { for } 20-25 \text { tons of pellets per trip. }\end{array}$ & $\begin{array}{l}\text { Additional investment is not } \\
\text { required; loading can be } \\
\text { organized by conventional truck. }\end{array}$ \\
\hline $\begin{array}{l}\text { Shipment in big } \\
\text { bags by rail }\end{array}$ & $\begin{array}{l}\text { Cost of big bag shipment }- \text { approx. } \$ 10(\sim 8 \\
\text { euros) per ton of pellets, railway tariff. }\end{array}$ & $\begin{array}{l}\text { Driveways (sidings) are } \\
\text { required. }\end{array}$ \\
\hline $\begin{array}{l}\text { Shipment in bulk } \\
\text { by rail (Hopper- } \\
\text { grain) }\end{array}$ & $\begin{array}{l}\text { Railway tariff - due to more efficient use of } \\
\text { hopper space, it can be cheaper than using } \\
\text { covered wagons and big bags. }\end{array}$ & $\begin{array}{l}\text { Driveways, access to rolling } \\
\text { stock, and equipment for } \\
\text { loading wagons through top } \\
\text { hatches are required. }\end{array}$ \\
\hline $\begin{array}{l}\text { Packing pellets } \\
\text { in bags of } 10- \\
20 \mathrm{~kg} \text { in the } \\
\text { plant and retail } \\
\text { shipping } \\
\text { packaging }\end{array}$ & $\begin{array}{l}\text { Cost of packing, cost of transportation for } 20- \\
25 \text { tons of pellets per trip; additional costs can } \\
\text { be offset by higher sales prices for pellets that } \\
\text { are packed in accordance with consumer needs. }\end{array}$ & Packing equipment, autoloader. \\
\hline
\end{tabular}

Shipment in bulk by road is not organized in Russia, so it is not taken into consideration

"VTC" is located near the OAO "Vyborg Cellulose" sawmill and Vyborg port. "VTC" has its own port infrastructure [51] and "VTC" contributes significantly to the turnover of wood pellets in Vyborg port. Smaller producers wishing to supply wood pellets through the Port of Vyborg sometimes face considerable waiting times at the harbor. This small port has a low load, thus making it seem attractive to small pellet producers with 2,500-5,000 tons of wood pellets. However, the loads of relatively small amounts of wood pellets need to be supplied at a time when suitable sea transportation is available. Currently, traders buy pellets from producers and store them in the port before transportation to European ports. Thus, shipment in big bags by road and by rail seems a better option for this case.

Truck logistics is an important environmental aspect to be considered, e.g., whether return trips from the seaport toward the pellet plants are done by loaded or empty trucks and for what transportation the trucks could be utilized during the return trip. However, greenhouse gas 
(GHG) emissions are reduced for empty return trips in comparison to loaded trucks. Jonker et al. have assumed (based on Hamelinck et al. [24]) a 60\% GHG emission reduction for a 100-km distance for 16-32 ton empty versus loaded trucks [58]. Another question is to what product chain the emissions from return trips by loaded trucks would be allocated.

\subsection{Cargo handling options in the seaport}

Concerning cargo handling at the Seaport of St. Petersburg, there are restrictions and not all possible options (Table 3) are suitable. Specialized wood pellet hoppers, which are wood pellet fabric bins typically equipped with a pellet feed hole and an air valve ( $200 \mathrm{~mm})$ and manhole, do not exist in Russian ports. Furthermore, in the development program of the infrastructure for wood pellets of Ust-Luga port (Section 2.3) [59], for example, hopper conveyors are not planned, as they are not considered economically beneficial.

Table 3 Cargo handling options in the Seaport of St. Petersburg (Stage 2), adapted from [28].

\begin{tabular}{ll}
\hline Option & Features and costs \\
\hline $\begin{array}{l}\text { Pellet handling in } \\
\text { big bags or in }\end{array}$ & Handling is easier and cheaper than for other \\
retail packages & options. Approximate cost of handling in the port \\
& of St. Petersburg: $\$ 10$ ( $~ 8.5$ euros $)$ per gross ton. \\
& This is the most economical option if the buyer is \\
& willing to take the pellets in big bags in a large \\
& quantity. \\
& There could be costs related to long-term storage \\
& of the ship's pellets in the port area before sea \\
& transportation.
\end{tabular}

Handling of Handling requires great effort and takes a lot of pellets shipped from the plant in big bags, unpacking of big bags into the holds of dry bulk vessels Handling of pellets delivered from the plant by bulk by rail in hopper wagons St. Petersburg: \$14 ( 11 euros) per gross ton. During handling big bags are destroyed and accumulate related to storage of the ship's pellets in the port area.

With a floating crane: Use of a floating crane is currently the most economical method of pellet handling in the port. In case of a properly St. Petersburg could be approximately $\$ 10(\sim 8$ time. Approximate cost of handling in the port of recycled. During pellet delivery by vehicles, costs structured scheme, costs of handling in the port of euros) per ton. Additional economic savings are achieved by eliminating the big bags.

Through a dedicated terminal: Potentially the most effective and economical option. Using existing bulk terminals is difficult for several reasons, the main one being their use by other export cargo.

Requirements

Special conditions are not required. Could be organized by any stevedoring company.

Special conditions are not required. Could be organized by most stevedoring companies of the port.

Heavy-duty crane equipment and sidings on the dock are required.

A dedicated terminal requires space in the port with a quay wall and specialized terminal equipment, including at a minimum: a device for bottom unloading of hoppers, automated warehousing, conveyors for fast loading of pellets into the holds of the vessel. 
At the St. Petersburg port, big bags and bulk shipments in the holds of ships are possible cargo handling options. Such cargo handling includes procedures associated with the accumulation of wood pellets from different suppliers, as well as acceptance and quality control of biofuels, the sale of such "teams" parties under long-term contracts, etc. For the port of St. Petersburg, pellet handling in big bags or in retail packages $(\sim 15 \mathrm{~kg})$ appears to be a better option than pellets delivered in bulk by rail hopper wagons, due to competition with other cargos.

Sometimes the cargo handling in the seaport requires more time than expected, as can be seen from the example of a large wood pellet transpors handled at Ust-Luga at the end of 2010. Novo Yeniseisk LHK [60], a biofuel producer from the Krasnoyarsk region, supplied a vessel transporting wood pellets to Denmark. According to company information, the ship arrived in Russia before the Russian New Year, (on December 31, 2010) and on January 2, 2011, it began loading of pellets in the port of Ust-Luga, at the timber terminal "Factor." Loading of pellets was not completed until January 13, 2011. The long duration of wood pellet handling was explained by adverse weather conditions with frequent rain, snow, and freezing rain [61]. Another possible reason could be a lack of manpower because of the holiday period.

Prospects for wood pellet shipping at the Ust-Luga port seem promising. A specialized terminal for wood pellet handling was opened in September 2014, the only such facility in Russia [61]. This could improve the speed of cargo handling and be beneficial to the logistics chain. Selkimäki et al. [62] suggest that pellets tend to disintegrate during long-distance transport, loading, and unloading. The amount of fines can increase and pellet quality can decrease. One important quality aspect is that a part of the dry matter of wood pellets is lost during handling in export ports and shipment [58], which decreases the heating value. Jonker et al. [58] have assumed total dry matter loss of wood pellets as $7 \%$ for the whole supply chain from forest to power plant. The extent of the loss, however, depends on the specific supply chain.

\subsection{Receipt of wood pellets at the destination port}

Receipt of wood pellets (Table 4) at Western European destination ports seems more efficient than in Russian ports. Hoefnagels et al. [63] and Hansson et al. [64] suggest that large (coal) power plants are often located close to sea terminals or inland waterways, for efficient fuel supply and cooling purposes, and such installations can handle wood pellets in bulk. Several large power plants in Western Europe have their own loading capacities for receiving bulk fuel. For example, the biggest consumer of wood pellets in Denmark, "Energi E2," has its own terminal, which is located next to its power plant. Pellets from this terminal go directly to the furnace of the power plant [28].

Table 4 Receipt of wood pellets at the destination port (Stage 3), adapted from [28].

\begin{tabular}{|c|c|c|}
\hline Option & Features and costs & Requirements \\
\hline $\begin{array}{l}\text { Receipt of } \\
\text { pellets in bulk }\end{array}$ & $\begin{array}{l}\text { The most popular option, providing the recipient the } \\
\text { lowest cost and maximum flexibility. Traders receive } \\
\text { pellets in bulk, unload it at their warehouses, where } \\
\text { wood pellets are sorted, if necessary, packed in big } \\
\text { bags or retail packaging, and are forwarded to final } \\
\text { consumers or retailers. }\end{array}$ & $\begin{array}{l}\text { Specialized equipment for } \\
\text { unloading is required. Such } \\
\text { equipment is widely } \\
\text { available at European ports. }\end{array}$ \\
\hline
\end{tabular}


Receipt of Unloading is carried out as for other cargo. As a rule, No special requirements. pellets in big big bags are unpacked after unloading and go to bags recycling, which also leads to additional costs. Unloading operations are relatively time-consuming and take a long time for large volumes of pellets. After unpacking of big bags, the pellets are treated in the same manner as bulk pellets.

Receipt of Unloading is carried out as for other cargo. After pellets in retail unloading, the consignment is split and delivered to packages retailers or consumers. It is a potentially attractive option but makes sense only when targeting the retail market.

With Russia pellets, this option is normally used for pre-orders of pellet production and packaging in accordance with given specifications.

European ports can receive Russian wood pellets in large volumes. However, infrastructure restrictions in Russian ports mean that Russian pellet suppliers cannot benefit from the large volume capacity. Imports from Russia generally arrive using short sea shipping with about 4,000-5,000-ton loads. For comparison, shipments from the USA are delivered in Panamax ocean vessels with 60,000-80,000-ton maximum loads [23].

\section{Economic conditions}

Lamers et al. [65] suggest that economic viability is a key constraint for the international solid biofuel trade. For wood pellets, production and transport costs and exchange rates are crucial. The cost structure of wood pellets starts from feedstock cost and ends with delivery price to buyers/traders as presented in Figure 6. Costs related with the feedstock and pellet production are outside the scope of this study. However, since their share of total wood pellet cost is significant, they need to be considered by pellet producers [66].

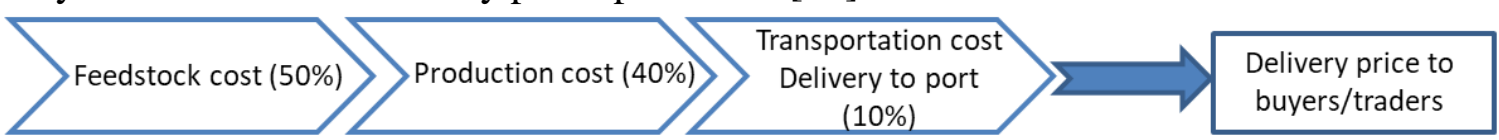

Fig. 6. Basic wood pellet cost structure, adapted from [66].

The market for pellets is still in the formative stage and actively developing. The Russian domestic price for pellets has increased slightly from year to year, mainly because of increased demand on the world market [67]. The majority of pellets are shipped under long-term contracts, which thus far have been more expensive than short-term contracts because buyers pay a premium for supply security. Freight costs from Russia were between $€ 20 /$ ton and $€ 25 /$ ton in 2009. Free on Board (FOB) prices for wood pellets from Russia ranged from $€ 105 /$ ton to $€ 119 /$ ton [68].

The transportation costs of wood pellets vary depending on the companies involved, destination, point of origin, and contract terms, etc. The cost of pellet transshipment is different in different ports. For example, in Ust-Luga (December 2009) the transportation cost was €9/ton, whereas at the St. Petersburg port a comparable operation was about $€ 12-13 /$ ton. The retail price of Russian pellets in Western Europe was within a price range of €210-390/ton (including VAT) in 2009 [69]. Describing wood pellet FOB prices at different harbors, Lamers et al. [70] suggest that the 
average price per supply, as published between May and November 2012, was €123/ton for St. Petersburg and Vyborg harbors.

The maximum prices for wood pellet shipments FOB-St. Petersburg has been investigated [49,71]. In summer 2012, "VTC" sold wood pellets to European consumers for a maximum price of $€ 116 /$ ton on terms of FOB-Saint Petersburg. Other major manufacturers of pellets produced and delivered pellets on FOB at lower prices in 2012 [49]. In 2013, the price for American buyers reached a maximum of US $\$ 1,850 /$ ton ( $€ 1,381 /$ ton). Wood pellets were sold to a Swedish trader and Danish energy company for $€ 300 /$ ton. The study did not give a reason for the vast price difference, and possible mistakes in the documentation cannot be excluded [72].

In Europe, USA and Canada, wood pellet market price information is collected and published by companies such as Argust (CIF Ara) and Foex (Pellet Nordic CIF), and by research [22]. At the moment of writing, one such collection exists in Russia, an index made by IAA "INFOBIO," based on European index models. The index describes prices of sea shipments from several ports of the Russian Federation calculated from weighted average prices. Data for pellets sold on the terms of FOB-St. Petersburg and FOB-Vyborg are given in Fig. 7 [73].

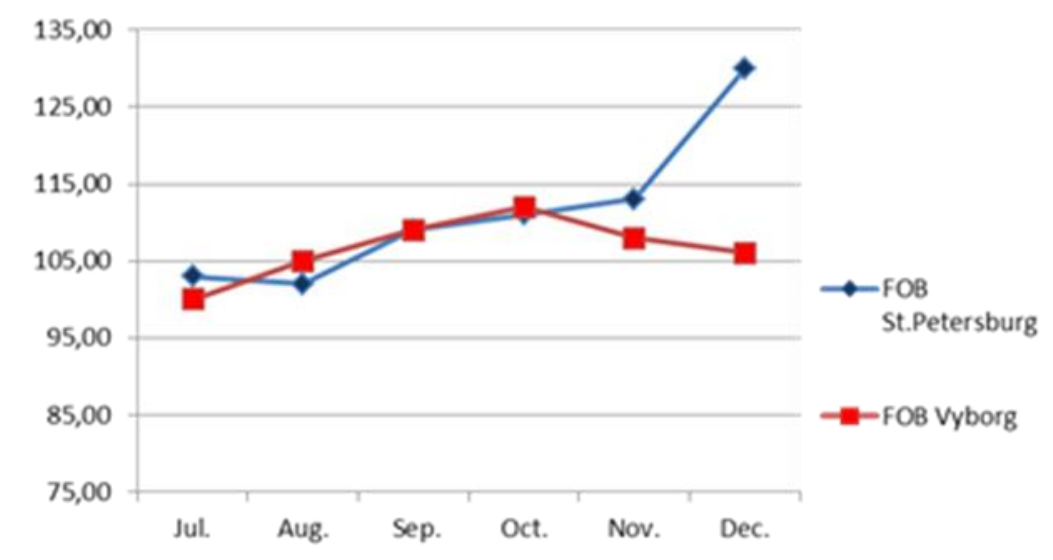

Fig. 7. Price index for industrial wood pellets, $€ /$ ton, 2013, adapted from [73].

\section{Environmental conditions}

Magelli et al. [21] found that greenhouse gas (GHG) and air pollutant emissions from longdistance ocean transportation of wood pellets account for the major share of total emissions in the supply chain. Both [21] and Cocchi et al. [74] evaluate non-renewable GHG emissions from wood pellet logistics by ship (including necessary truck and railway transportations) as being significant. Jonker et al. [58] have calculated the carbon balance in their analysis of the wood pellet supply chain from Southeastern USA to Europe. The GHG emissions are supply-chainspecific, depending on the production and transportation volume. In their analysis, Jonker et al. [58] found that GHG emissions for ocean transport are 92.4 grams of carbon dioxide $\left(\mathrm{CO}_{2}\right)$ equivalents per ton of wood pellets, with the shipment distance being 7,200 km. In the supply chain studied, only the pelletizing process produced more GHG emissions $\left(160.5 \mathrm{gCO}_{2} \mathrm{eq} / \mathrm{ton}\right)$ than the shipment [58]. McBride et al. [75] further warn that trucking and shipments of pellets consume large amounts of fossil fuels, which decreases the environmental benefits gained from renewable energy production from wood pellets. 
Sikkema et al. [76] and Hansson et al. [77] suggest that there is a potential for GHG reduction from wood pellet value chains. Magelli et al. [21] recommend shorter ocean transportation distances for wood pellets to improve the energy balance (the ratio of energy gained from the use of wood pellets for energy production in comparison to energy consumption of the supply chain) of the wood pellet supply chain. In contrast, Ryckmans and André [70] found that wood pellet supply chains where pellets are transported to end-customers at a long distance from the pellet plant are not necessarily less energy efficient or more carbon intensive per MWh primary energy produced than centralized pellet supply chains. In their study, wood pellet imports from Russia (through an undefined seaport) to two Belgian power plants were, however, at the more energyand carbon-intensive end compared to imports from European countries and Canada.

Pellets imported to Sweden from Latvia, Russia, and Canada that use biomass in the drying process, e.g. biomass-based electricity, may reach relatively low levels of total GHG emissions compared to other wood pellet chains [77]. Thus, depending on the specific production method of the wood pellets, and in view of the shorter shipping distances from Russia, Russian wood pellets have the possibility to remain attractive, from an environmental viewpoint, in comparison to those shipped from North America. The demand for Russian wood pellets may depend on the level of customer awareness of supply chain sustainability aspects, such as impact on global warming and health, and on Russian importers' ability to produce pellets with low GHG emissions, for example.

Directive 2012/33/EU [78] on the sulphur content of marine fuels entered into force at the beginning of 2015 and sets maximum sulphur content and emissions for marine transportation in the EU. In practice, this means that the marine vessels will have to either switch to fuel with lower sulphur content, or start cleansing their emissions, for example, by introducing sulphuric oxide scrubbers. These restrictions have required investments in sulphur reduction technologies, which may affect the attractiveness of sea transportation of wood pellets in comparison to transportation by truck or train. These directive requirements for marine fuels are valid for all ships entering EU ports or plying the waters of the EU; thus, Russia should fulfill these requirements in case of transportation of any product to European ports. Directive 2012/33/EU [78] threatens to raise the cost of shipping in the Baltic Sea. Ship freight costs are expected to rise significantly and, as a result, the price of wood pellet transportation through the Northwest Russian seaports may increase.

The location of the St. Petersburg port on the Baltic Sea shore is a special challenge for wood pellet shipping due to stresses already placed on the ecosystem and biodiversity. The Baltic Marine Environment Protection Commission (HELCOM) [79] is actively developing environmental policy objectives to protect the sea. According to the draft roadmap on sustainable Baltic Sea shipping published by HELCOM in 2014 [80], marine transportation should, e.g., study opportunities to utilize alternative fuels (e.g., biofuels) and actively develop and apply technologies for air emission reduction (e.g., GHG and $\mathrm{NO}_{\mathrm{x}}$ ).

\section{Regulatory conditions}

Quality standards provide customers with guarantees about minimum product quality and help to ensure product functionality and compatibility, which facilitate interoperability and support consumer safety and public health certification [81]. García-Maraver et al. [82] present a comparison of different pellet standards currently existing in European countries, such as Austria, Sweden, Germany, Italy, and France. The pellet quality parameters that appear most 
frequently in standards and recommendations of different countries are pellet size, moisture content, heating value and ash content.

The DINplus and ENplus pellet certifications are two popular pellet quality certification standards accepted by regional pellet producers and pellet consumers (Table 5) [83]. ENplus has two quality classes, which are designated A1 and A2. Class A1 refers to premium quality and A1 pellets are used in private household boilers or stoves. A1 pellets produce the least amount of ash and fulfill higher requirements than Class A2, which is used in larger installations [84]. DINplus is a German standard for pellets and briquettes. DINplus is currently the most important quality certification for wood pellets worldwide [81].

Table 5 Comparison of parameters for DIN and EN-plus pellets, adapted from [83].

\begin{tabular}{|l|c|c|c|c|}
\hline \multicolumn{1}{|c|}{ Parameter } & Unit & DINplus & ENplus-A1 & ENplus-A2 \\
\hline Diameter & $\mathrm{mm}$ & $4 \sim 10$ & $6 \sim 8$ & $6 \sim 8$ \\
\hline Length & $/$ & $<5 \times \mathrm{D}$ & $3.15 \leq \mathrm{L} \leq 40$ & $3.15 \leq \mathrm{L} \leq 40$ \\
\hline Bulk density & $\mathrm{kg} / \mathrm{dm}^{3}$ & $>1.12$ & - & - \\
\cline { 2 - 5 } & $\mathrm{kg} / \mathrm{m}^{3}$ & - & $\geq 600$ & $\geq 600$ \\
\hline Heat value & $\mathrm{MJ} / \mathrm{kg}$ & $>18$ & $\geq 16.5$ & $\geq 16.3$ \\
\hline Moisture content & $\%$ & 10 & $\leq 10$ & $\leq 10$ \\
\hline Abrasion & $\%$ & $<2.3$ & no & no \\
\hline Fine material $(<3.15 \mathrm{~mm})$ & $\mathrm{no}$ & $\mathrm{no}$ & $\leq 1$ & $\leq 1$ \\
\hline Ash content & $\%$ & $<0.5$ & $\leq 0.7$ & $\leq 1.5$ \\
\hline Chlorine content & $\%$ & $<0.02$ & $\leq 0.02$ & $\leq 0.03$ \\
\hline Sulfur content & $\%$ & $<0.04$ & $\leq 0.05$ & $\leq 0.05$ \\
\hline Nitrogen content & $\%$ & $<0.3$ & $\leq 0.03$ & $\leq 0.05$ \\
\hline Heavy metals & $\%$ & regulated & regulated & regulated \\
\hline
\end{tabular}

Currently, there is no national standard for wood pellet quality in Russia. Russian producers are mainly oriented toward DINplus. Trade sources report that the EU currently does not require certification for Russian wood pellets as long as the product is manufactured in compliance with DINplus [85]. Unexpected delays in cargo handling in the seaport, as described in Section 4.2, can lead to undesirable degradation of pellet quality. For example, if wood pellets are subject to excess moisture, this might be harmful because it may cause break-up of the pellets [86].

Sustainability standards and certification systems that are applicable to wood pellets and linked with existing legislation [74] are being developed at both the international and national level. Russian exporters need to respond to customer inquiries regarding certificates and compliance with standards. The upcoming international ISO 13065 standard sustainability criteria for bioenergy [87], which overarches the entire supply chain of wood pellets, is of special interest to Russian wood pellet exporters.

Several certification systems concentrate on the wood material acquisition stage of the wood pellet supply chain, including, for example, the widely recognized Sustainable Forestry Initiative (SFI), Forest Stewardship Council (FSC) certification, which is recognized in the USA and has a solid reputation in Europe, and the Program for the Endorsement of Forest Certification (PEFC). Currently, there is no certification of wood pellet sustainability in Russia according to Western certification systems, for example, the FSC. Unreliable data about the quality of the products and a lack of production certification decrease Russian pellet competitiveness on world pellet markets [16]. Certification systems include the requirement of compliance with national legislation and Russian pellet exporters, by participating in certification systems, could show 
commitment to sustainability that exceeds the minimum level set by legislative sustainability criteria [88] with positive effects on the attractiveness of Russian wood pellets.

Cocchi et al. [74] show that wood pellet sustainability standards and certification systems provide benefits such as reduced risk, which means lower prices in practice. Qian and McDow [66] instead predict that forest management and consequently pellet feedstock costs could increase due to certification requirements.

Specific legislation concerning pellets as a product does not exist in the EU [89]. The EU has stated political interest in creating EU-wide binding sustainability criteria for solid and gaseous biomasses for energy use [90]. However, a draft proposal for a directive on sustainability criteria for solid and gaseous biomass used in electricity and/or heating and cooling and biomethane injected into the natural gas network prepared by the EU Commission was dropped in 2013 due to opposition [91]. Gamborg et al. [90] predict that if binding sustainability criteria for solid biomass based fuels are adopted in the EU, they are likely to be similar to the criteria given in directive 2009/28/EC [92] on the promotion of energy from renewable energy sources (RES) for liquid and gaseous transportation biofuels and bioliquids for other energy use than transport. Russian wood pellet exporters need to be aware of this development.

To minimize barriers to trade arising from different national sustainability criteria for solid biomass fuels, the EU Commission gave non-binding recommendations to EU Member States for national criteria in 2010 [93]. So far, the UK, Belgium, and Italy have introduced national solid biomass sustainability criteria [94], and the Netherlands and Spain have initiatives toward developing national criteria [74]. Thus, in the absence of EU-wide legislation, Russian wood pellet exporters need to follow the development of binding sustainability criteria at the national level.

\section{Discussion}

Transportation and logistically related decisions should be based on an analysis of each specific situation, with detailed study of the investment and production capacities of the individual companies involved. For instance, in one case packing pellets to be shipped in paper bags in Russia may be cost-effective, and in another case implementation of paper bag packaging in Russia may be very difficult and expensive. It is clear that handling of big bags will be one of the more economical options in Russian ports. The use of big bags is typically cheaper for the customer but not so economical for the Russian supplier [28].

The various combinations of options should be considered for each main stage of wood pellet transportation and their costs assessed, taking into account direct transport costs and logistical limitations, as well as any necessary investments in equipment and infrastructure. Regulation through legislation and standards may impose additional limitations and cause further necessary investments.

\subsection{Challenges}

The export of Russian wood pellets to Europe can be considered as relatively well developed, although systemic problems with transportation have not been resolved and these continue to hamper more intensive development of industrial production and supply. This study has noted that wood pellet logistics through Russian ports face many constraints. For example, wood pellet loading onto the vessel can often be slow, creating additional expenses, and not all options in the logistics chain are suitable for Russian ports. The absence of port infrastructure for the 
collection, storage, dust removal and loading of pellets for bulk shipment by large-capacity transport is a serious problem. Large-capacity trucks could give a competitive advantage to Russian producers exporting wood pellets to Europe. However, the use of large-capacity trucks requires suitable port and other infrastructure, such as good roads. For efficient operation, Russian ports require substantial investment to improve current infrastructure.

In addition to the absence of a good logistics infrastructure, other factors hindering development of Russian wood pellet exports include unreliable quality data about the product, a lack of domestic demand (reducing motivation to invest in pellet production plants and exposing producers to currency fluctuations and political risks), weak price formation, and a lack of specific legislation regarding energy production from wood fuel. Development of the EU market area with regard to legislation and standards concerning energy production from biomass increases the need for Russian pellet suppliers to establish a sustainable supply chain for wood pellet transportation through the Northwest Russian seaports.

Russian exporters need to be aware of both national and EU-level developments in sustainability criteria for solid biomass-based fuels. Early preparation for changes in legislation in target markets may help Russian exporters to avoid additional and unexpected costs. Thus far, legislation, standards and certification systems do not seem to set direct requirements on the logistics life cycle stages and tend to concentrate on pellet production. However, logistics contributes to the total sustainability of the pellet production chain. Requirements that would be especially relevant from the storage and transportation perspective relate to greenhouse gas emissions throughout the entire life cycle of the pellets and ensuring full traceability of the origin of the pellet raw materials, as in 2009/28/EC, through uninterrupted and transparent information exchange in the whole supply chain. Thus, recording the origin of each pellet consignment [66] and ensuring continuous communication of this information during storage and transportation would be necessary.

As was mentioned in section 2, the Russian wood pellet industry is export-oriented, which implies that the industry depends on foreign consumers, mainly the EU. Thus, if EU demand for wood pellets declines or the EU can satisfy demand from its own wood pellet production and/or wood pellets from North America and other regions offer a better price on the markets, Russian wood pellets will suffer due to the lack of a domestic market. Industries that are export-oriented face risks from weak demand from foreign consumers, as can be seen with the price of fossil fuels in 2015. The Russian economy depends significantly on the export of oil and natural gas, and if the price goes down it negatively impacts the economy of the country. It is clear that if domestic Russian wood pellet demand starts to grow, for example, due to replacement in power plants of coal and natural gas by wood pellets, it will have a positive impact on Russian wood pellet industry development.

\subsection{Development of wood pellet transportation through selected seaports}

Significant growth in wood pellet transportation through the three ports studied is not guaranteed, although the prospects of Ust-Luga port seem quite promising. Successful realization of the Ust-Luga development plan could significantly increase the wood pellet turnover of the port. One of the competitive advantages of Ust-Luga port is the relatively long distance from settlements and the absence of severe restrictions on the expansion of the port and related infrastructure. A factor negatively affecting the prospects of Ust-Luga is that transport by large vessels is not possible in the Ust-Luga port. The depth of the river is 6-8 meters, so the port is only suitable for ships with a capacity of 800 to 4 million tons. St. Petersburg port, which is able 
to handle large vessels, is focusing more on other products, and thus large pellet shipments, as found from Canada and the USA, are difficult to foresee.

The Port of Vyborg might not be able to increase the volume of wood pellet transportation due to the lack of growth in exports by "Vyborg Timber Corporation," which is not operating stably. In the current economic situation, an increase in wood pellet supply through the Vyborg port by other producers is not foreseeable. Thus, the turnover of wood pellets in the port could be unchanged or even decline.

This study has noted that prices for wood pellets in Russia are not stable, with different ports and wood pellet producers offering very different prices. There are many reasons for the price differentials, including changes in the oil, gas and coal markets. However, wood pellet prices are generally increasing and could continue to do so, at least in the short and medium term.

Improving the logistics chain could solve many problems and also decrease the price of transportation by sea. For instance, if special pellet terminals existed in Russian ports, it could reduce the time of handling, which can give cost benefits. Due to the lack of such specialized terminals, flexible bulk containers, such as MK-14-10 with a capacity of 9 tons of pellets are used, which are very expensive. Costly maintenance and transportation mean that reuse of empty containers gives only small savings [28].

\section{Conclusions and recommendations}

The majority of Russian wood pellet producers exist to serve demand from Europe. Thus, improvement in the logistics of Russian wood pellets can play a major role in the future of the Russian wood pellet industry. In describing the transportation of Russian wood pellets, including economic, environmental and regulatory perspectives, this study has shown that Russian wood pellet exports may have difficulties in fulfilling expectations due to a number of challenges in transportation. Weak seaport infrastructure is one of the bottlenecks in wood pellet exports. Without significant improvements in port infrastructure, the Russian wood pellet industry might disappear from the global wood pellet market. However, the implementation of such changes is uncertain in the current Russian political and economic circumstances. In addition, the political situation in Russia, including the ongoing conflict in Ukraine [95] and the impact of sanctions on the EU-Russia relationship, make predictions regarding the future development of wood pellet transportation through Northwest Russian seaports uncertain.

The results of this study indicate that the Russian wood pellet industry needs to prepare for the possibility of adoption of sustainability criteria for wood pellets from European customers. Utilization of existing international certification systems applicable to the pellet production chain could be beneficial, as well as early compliance with future standards and legislative requirements, which would ensure continuance of business in the European market area and competitiveness against other major pellet exporters, such as the USA and Canada. Russian wood pellet producers aiming at the EU market need to take under their control both the supply chain of raw material and the transportation stage to ensure fully traceable pellets with consistent quality.

It is time for Russia to develop its port infrastructure and fulfill all the necessary criteria to compete with its competitors. Competition and subsidy policies in European countries such as Sweden and Denmark, and potential changes in EU sustainability policies and legislation threaten the competitiveness of Russian wood pellets on the global wood pellet market. Additionally, the eastern region of Canada, which is very convenient for shipping pellets across 
the Atlantic ocean to the EU, has been active in recent years in development of pellet production, procurement, and logistics [96]. In contrast, sustainability criteria pose a potential challenge for producers from the USA because pellets in the USA are mostly sourced from private forest owners who are not involved in any certification program [97]. This fragmentation of supply may impact potential European buyers, as many buyers are required to purchase certified pellets. Clearly, such challenges may prove to be an opportunity for Russian pellet producers, but the question is whether Russian pellet producers themselves are capable of keeping pace with the challenges that lie ahead.

The prerequisite for planning either short-term or long-term sustainable business efforts in a certain market area is compliance with all applicable local laws. Russian wood pellet exporters' awareness of the development of EU legislation and ability to take necessary actions in good time are important prerequisites of continuity, i.e. sustainability of the business. Furthermore, the EU has taken regulatory initiatives to establish sustainability criteria for different biofuels and, thus, sustainability thinking has become integrated into legislation. Requirements from customers or other stakeholder groups concerning, for example, the quality and composition of wood pellets, as well as environmental, social and economic sustainability aspects, are often as compelling to the producer as legislative sustainability criteria. Standards and certification systems could be a tool for Russian wood pellet exporters to demonstrate compliance with customer requirements.

Globally, the environmental impacts of GHG emissions and energy consumption are well recognized and European customers are likely to require such information from Russian wood pellet producers. Emissions of air pollutants from wood pellet transportation are discussed in research literature. Furthermore, local sensitivities related to sulphur emissions from the use of marine fuels and protection initiatives for the Baltic Sea characterize the environmental requirements of the European market area. In the long term, Russian wood pellet exporters should expect an increase rather than a decrease in environmental regulations for operations in the EU.

In addition to environmental sustainability, socio-economic sustainability is equally important for the overall sustainability of wood pellet production and trade. From a long-term perspective, infrastructure development of ports implies job creation, which contributes to local and nationwide socio-economic prosperity. The job creation is, however, not only a matter of number of jobs created, the quality of the jobs also needs to be taken into consideration, for example, safe and healthy working conditions. Furthermore, at a larger scale, the quality of the surrounding environment of the pellet transportation operations needs attention: safe and healthy living conditions for local residents need to be maintained to ensure public acceptance. For example, traffic safety cannot be compromised due to increasing pellet loads.

The EU is the world's largest consumer of pellets, with stable growth in wood pellets consumption. However, if Russia does not address the problems mentioned in this paper, export of Russian wood pellets to the EU may be expected to remain constant or even decline. This study suggests that the main challenges are related to a lack of domestic consumption and issues concerning transportation by sea. From a long-term perspective, without major changes there is a possibility that Russian wood pellets may cease to be an important player on global markets.

The purpose of the current study was to present a general overview of transportation of wood pellets through Russian seaports, showing the logistical, economic, environmental, and regulatory conditions and considering future perspectives. The study is of value in that it provides a foundation for the creation of possible recommendations for improvements to wood 
pellet transportation infrastructure, as well as for meeting sustainability regulations. This research extends our knowledge of seaborne wood pellet transportation and can be of interest not only to future research, but also to wood pellet producers, exporters, and traders within and outside of Russia. This study covers Northwest Russian seaports; however, the logistical, economic, environmental, and regulatory conditions presented may be applicable to assessment of other ports, as well as road and rail transportation of other solid biofuels.

This research has raised many questions in need of further investigation. The model discussed can serve as a starting point for further development and wider analysis. More research is required to enable more complex analysis that takes into account factors such as price ratios in different market segments, the choice between export and domestic markets, and the ability to guarantee a certain level of pellet quality. This study can be a starting point for further discussion of possible improvement of Russian wood pellet transportation.

The social sustainability aspects of wood pellet transportation were outside the scope of the study. However, the importance of social sustainability cannot be denied. For example, ISO 13065 will probably raise the importance of sustainability issues in bioenergy supply chains and the bioenergy business. Sustainable forest management initiatives and sustainability requirements concerning biofuel raw material acquisition may be a further interesting future research area.

\section{Acknowledgements}

Part of this work was funded by the Fortum Foundation, Finland (Project 201300010), whose support is gratefully acknowledged. In addition, part of this work was carried out in the Sustainable Bioenergy Solutions for Tomorrow (BEST) research program coordinated by FIBIC Ltd. and CLEEN Ltd. with funding from the Finnish Funding Agency for Innovation, Tekes. We would like to thank Peter Jones (LUT) for his valuable comments. 


\section{References}

[1] Heinimö J, Junginger M. Production and trading of biomass for energy-an overview of the global status. Biomass and Bioenergy 2009;33:1310-20.

[2] Junginger M, van Dam J, Zarrilli S, Mohamed FA, Marchal D, Faaija A. Opportunities and barriers for international bioenergy trade. Energy Policy 2011;39(4):2028-42.

[3] Olsson O, Hillring B, Vinterbäck J. European wood pellet market integration-a study of the residential sector. Biomass and Bioenergy 2011;35,(1):153-60.

[4] Peksa-Blanchard M, Dolzan P, Grassi A, Heinimö J, Junginger M, Ranta T, et al. Global wood pellets market and industry: policy drivers, market status and raw material potential. IEA Bioenergy Task 40, http://www.bioenergytrade.org/downloads/ieatask40pelletandrawmaterialstudynov2007final .pd 2007 [accessed 05.04.14].

[5] WBA (World Bioenergy Association). Global Bioenergy Statistics; 2015.

[6] Goh CS, Junginger M, Cocchi M, Marchal D, Thrän D, Hennig C, et al. Wood pellet market and trade: a global perspective. Biofuels Bioprod Biorefin 2013;7:24-42.

[7] Bradley D, Hektor B, Wild M, Deutmeyer M, Schouwenberg PP, Hess R, et. al. Low cost, long distance biomass supply chains. IEA Bioenergy Task 40, https://www.svebio.se/sites/default/files/t40-low-cost-long-distance-biomass-supplychains.pdf ; 2013 [accessed 08.03.15].

[8] Wood markets. Wood pellet market outlook. Monthly international report 2013. http://www.woodmarkets.com/wp-content/uploads/2014/02/WMM-Feb13.pdf $\quad ; \quad 2013$ [accessed 21.02.15].

[9] REN21 (Renewable Energy Policy NetWork), Renewables 2014 global status report, http://www.ren21.net/portals/0/documents/resources/gsr/2014/gsr2014_full\%20report_low \%20res.pdf ; 2014 [accessed 18.11.14].

[10] Pöyry central scenario. Wood pellet demand; 2014.

[11] Kuparinen K, Heinimö J, Vakkilainen E. World's largest biofuel and pellet plantsgeographic distribution, capacity share, and feedstock supply. Biofuels Bioprod Biorefin 2014;8(6):747-54.

[12] Mola-Yudego B, Selkimäki M, González-Olabarria JR. Spatial analysis of the wood pellet production for energy in Europe. Renewable Energy 2014;63:76-83.

[13] Heinimö J, Lamers P, Ranta T. International trade of energy biomass - an overview of the past development. In: Proceedings of the 21st European biomass conference and exhibition. Copenhagen, Denmark; 2013.

[14] Scarlat N, Dallemand JF, Motola V, Monforti-Ferrario F. Bioenergy production and use in Italy: Recent developments, perspectives and potential. Renewable Energy 2013;57:448461.

[15] Whatwood.ru. Russian pellets on the global market. http://whatwood.ru/english/russianpellets-on-the-global-market/ ; 2013 [accessed 18.12.14].

[16] Proskurina S, Heinimö J, Mikkilä M, Vakkilainen E. The wood pellet business in Russia with the role of North-West Russian regions: present trends and future challenges. Renew Sustain Energy Rev 2015;51:730-40.

[17] USIPA (U.S. International Pellet Association). The Outlook for Wood Pellet Demand. In: USIPA: 3rd Annual Exporting Pellets Conference. Paris, France; 2013.

[18] Junginger M, Bolkesjø T, Bradley D, Dolzan P, Faaij A, Heinimö J, et al. Developments in 
international bioenergy trade. Biomass and Bioenergy 2008;32(8):717-29.

[19] Mobini M, Sowlati T, Sokhansanj S. A simulation model for the design and analysis of wood pellet supply chain. Applied Energy 2013;111:1239-49.

[20] Thomson H, Liddell C. The suitability of wood pellet heating for domestic households:A review of literature. Renew Sustain Energy Rev 2015;42:1362-69.

[21] Magelli F, Boucher K, Bi HT, Melin S, Bonoli A. An environmental impact assessment of exported wood pellets from Canada to Europe. Biomass and Bioenergy 2009;33(3):434-41.

[22] Sikkema R, Steiner M, Junginger M, Hiegl W, Hansen MT, Faaij A. The European wood pellet markets: current status and prospects for 2020. Biofuels Bioprod Biorefin 2011;5(3):250-78.

[23] Orlov А. Экономические проблемы пеллетного производства. (Economic problems of pellet production). Saint Petersburg State Forest Technical University; [In Russian], http://spbftu.ru/UserFiles/Image/izvesti/20-205.pdf ; 2013. [accessed 05.04.14].

[24] Hamelinck CN, Suurs RAA, Faaij APC. International bioenergy transport costs and energy balance. Biomass and Bioenergy 2005;29:114-34.

[25] Hughes NM, Shahi C, Pulkki R. A review of the wood pellet value chain, modern value/supply chain management approaches, and value/supply chain models. Journal of Renewable Energy 2014;2014:ID 654158.

[26] Monteiro E, Mantha V, Rouboa A. Portuguese pellets market: Analysis of the production and utilization constrains. Energy Policy 2012;42:129-35.

[27] Rakitova O, Kholodkov V. The Pellet market and wood resources in the North-West of Russian. Baltic 21 Lighthouse project, The Baltic Sea Bioenergy, Promotion Project; 2009.

[28] Wood-Pellets.com. Выбор оптимальных логистических решений при экспортном производстве топливной гранулы. (Selection of optimum logistics solutions for the export production of wood pellets); [In Russian], http://www.wood-pellets.com/ ; 2005 [accessed 21.02.15].

[29] IRENA (International Renewable Energy Agency). Global Bioenergy Supply and demand projections, a working paper for REmap 2030; 2014.

[30] European Commision, 2015 Renewable energy directive [webpage], https://ec.europa.eu/energy/en/topics/renewable-energy/national-action-plans [accessed 15.03.15].

[31] Scarlat N, Dallemand JF, Monforti-Ferrario F, Banja M. Renewable energy policy frame work and bioenergy contribution in the European Union - An overview from National Renewable Energy Action Plans and Progress Reports. Renew and Sustain Energy Rev 2015;51:969-85.

[32] Hoefnagels R, Resch G, Junginger M, Faaij A. International and domestic uses of solid biofuels under different renewable energy support scenarios in the European Union. Applied Energy 2014;131:139-57.

[33] Heinimö J, Ojanen V, Kässi T. Junginger M. Views on the international market for energy biomass in 2020: results from a scenario study. Inter Journal of Energy Sector Manag 2008;2(4):547-69.

[34] DG Climate Action. 2030 Framework for climate and energy policies. Available online: http://ec.europa.eu/energy/en/topics/energy-strategy/2030-energy-strategy ; 2015 [accessed 18.09.15].

[35] IEA. International Energy Agency, Energy Policies of IEA Countries, 2014 Review, 2014.

[36] Pristupa AO, Mol APJ. Renewable energy in Russia: The take off in solid bioenergy? Ren 
Sustain Energy Rev 2015;50:315-24.

[37] Aleksandrova N. Characteristics of Creation of the Wood Pellets Market in Russia. Journal of Siberian Federal University Humanities \& Social Sciences 2008;1:443-54.

[38] Proskurina S, Vakkilainen E, Heinimö J, Mikkilä M. The Russian wood pellet business: exports to the Nordic area. In: Proceeding of the 22nd European biomass conference and exhibition. Hamburg, Germany; 2014.

[39] Raslavičius L, Kučinskas V, Jasinskas A, Bazaras Z. Identifying renewable energy and building renovation solutions in the Baltic Sea region: The case of Kaliningrad Oblast. Renew Sustain Energy Rev 2014;40:196-203.

[40] Buchholz T, Luzadis VA, Volk TA. Sustainability criteria for bioenergy systems: results from an expert survey. Journal of Clean Production 2009;17(1):86-96.

[41] Cherubini F, Strømman AH. Life cycle assessment of bioenergy systems: State of the art and future challenges. Bioresource Technology 2011;102(2):437-51.

[42] Liao et al. Is bioethanol a sustainable energy source? An energy-, exergy-, and emergybased thermodynamic system analysis. Renew Energy 2011;36:3479-87.

[43] Maes and Van Passel. Advantages and limitations of exergy indicators to assess sustainability of bioenergy and biobased materials. Environ Impact Assess Rev 2014;45:1929.

[44] personal information 19.06.2014 from a large Russian pellet manufacturer

[45] Information and Analytical Agency "Infobio". German Pellets GmbH запустит завод мощностью 500000 т/год пеллет в Нижегородской области. (German Pellets GmbH will launch a plant with capacity of 500000 ton/year of pellets in the Nizhny Novgorod region); 2014 [In Russian]. http://www.infobio.ru/news/2639.html [accessed 15.03.14].

[46] LesOnline. Экспорт пеллет из России в 2014 г. Таблица. (Wood pellets export from Russia in 2014); [In Russian], http://www.lesonline.ru/n/4C08F ; 2015 [accessed 18.09.15].

[47] BAF Vyborg LTD. Official website of Port Vyborg. http://www.vyborg.ru/org/baff/55.htm [accessed 18.08.14].

[48] Racitova O. The development of the pellet production in Russia. The national bioenergy union, the bioenergy international, Russia. Infobio; 2011.

[49] RosInvest.Com. «Выборгская лесопромышленная компания» выходит из кризиса и возобновляет производство пеллет. ("VTC" goes out of the crisis and resume the production of pellets); [In Russian], http://news.rambler.ru/20779612/ ; 2013 [accessed 08.11.14].

[50] Infobio 2013. Information and Analyticl Agancy "Infobio". Около 700,000 тонн топливных гранул было экспортировано из порта Выборга в Европу в 2012 году. (About 700,000 tons of wood pellets were exported from the port of Vyborg to Europe in 2012); [In Russian]. http://www.infobio.ru/en/node/2003 ; 2013 [accessed 21.08.14].

[51] Infobio 2011a. Information and Analyticl Agancy "Infobio". О создании специализированного биотопливного терминала думает компания «Фактор» из порта Усть-Луга, но пока рыночная конъюнктура не способствует реализации этих планов. (The company "Factor" from the port of Ust-Luga thinks about a specialized terminal for biofuel, but market conditions are not conducive to the implementation of these plans); [In Russian]. http://www.infobio.ru/news/1287.html ; 2011 [accessed 18.08.14].

[52] JSC "Sea Port of Saint-Petersburg". http://www.en.seaport.spb.ru/article/1/ [accessed 08.11.14].

[53] Wood-pellets.com. Некоторые особенности формирования экспортного рынка 
топливных гранул в России. (Some features of the wood pellet export market formation in Russia); [In Russian], http://www.wood-pellets.com/cgibin/cms/index.cgi?ext=content\&pid=1350 $; 2007$ [accessed 21.02.15].

[54] Karamysheva M, Henttu V, Hilmola OP. Logistics of North-West Russian and Rail Baltica: standpoints of private sector. Research report of Lappeenranta University of Technology. Scientific and Expertise Publications. 2013.

[55] Tarasov D. Wood pellet markets in Russia. Master's thesis of Lappeenranta University of Technology; 2009.

[56] Kolik A, Radziwill A, Turdyeva N. Improving Transport Infrastructure in Russia. OECD Economics Department Working Papers. 2015. No 1193.

[57] Mahonko A. OAO "Timber terminal"Factor". In: Conference by Information and Analytical Agency "Infobio": Энергия из биомассы:котельные и ТЭЦ на биотопливе, производство пеллет, брикетов, биогаза в России. (Energy from biomass: heat and power production from biofuel; production of pellets, briquettes and biogas in Russia). [In Russian]. St.Petersburg, Russia; 2014.

[58] Jonker JGG, Junginger M, Faaij A. Carbon payback period and carbon offset parity point of wood pellet production in the South-eastern United States. Global change biology bioenergy 2014;6(4):371-89.

[59] Infobio, 2014a. Information and Analyticl Agancy “Infobio". В начале следующей недели ОАО «Лесной терминар Фактор», расположенный в Усть-Луге, открывает первый пеллетный крытый склад длительного хранения в российском порту. (At the beginning of the next week, the "timber terminal Factor", which is located in Ust-Luga, opens the first pellet covered warehouse for long-term storage of wood pellets in Russia); [In Russian]. http://www.infobio.ru/news/2897.html ; 2014 [accessed 18.09.14].

[60] Novo Yeniseisk LHK. Новоенисейский лесохимический комплекс. (Novo-Yeniseysk wood-chemical complex); [In Russian], http://www.novo-lhk.ru/ ; [accessed 18.03.15].

[61] Infobio, 2011b. Information and Analyticl Agancy "Infobio". В порту Усть-Луга завершилась погрузка первой партии гранул нового пеллетного завода из Красноярского края. (In the port of Ust-Luga, the first loading of new pellets by plant of the Krasnoyarsk Territory is completed); [In Russian]. http://www.infobio.ru/news/757.html ;2011 [accessed 18.08.14].

[62] Selkimäki M, Mola-Yuudego B, Röser D, Prinz R, Sikanen L. Present and future trends in pellet markets, raw materials, and supply logistics in Sweden and Finland. Renew Sustain Energy Rev 2010;14(9):1368-75.

[63] Hoefnagels R, Junginger M, Faaij APC. The economic potential of wood pellet production from alternative, low-value wood sources in the southeast of the U.S. Biomass and Bioenergy 2014;71:443-54.

[64] Hansson, J., Berndes, G., Johnsson, F., Kjärstad J. (2009). Co-firing biomass with coal for electricity generation - an assessment of the potential in EU27. Energy Policy, 37 (4).

[65] Lamers P, Junginger M, Hamelinck C, Faaij A. Developments in international solid biofuel trade-An analysis of volumes, policies, and market factors. Renew Sustain Energy Rev 2012;16(5):3176-99.

[66] Qian Y, McDow W. The Wood Pellet Value Chain An economic analysis of the wood pellet supply chain from the Southeast United States to European Consumers. http://www.usendowment.org/images/The_Wood_Pellet_Value_Chain_Revised_Final.pdf ; 2013 [accessed 08.08.15]. 
[67] Pellets-briket.ru. Пелеты. Цена на пеллеты (Pellets. The price of pellets); [In Russian], http://pellets-briket.ru/cena-pellets.html ; 2012. [accessed 18.11.14].

[68] NREL (National Renewable Energy Laboratory). International Trade of Wood Pellets, Market Overview. http://www.nrel.gov/docs/fy13osti/56791.pdf ; 2013 [accessed 18.05.15].

[69] Cleandex. Обзор российского рынка древесных пеллет. (Review of the Russian market of wood pellets); [In Russian], http://www.cleandex.ru/articles/2010/08/25/russian_pellet_market_review ; 2010 [accessed 18.05.14].

[70] Lamers P, Hoefnagels R, Junginginger M, Hamelinck C, Faaij APC. Global solid biomass trade for energy by 2020: an assessment of potential import streams and supply costs to North-West Europe under different sustainability constraints. Global Change Biology Bioenergy 2015;7(4):618-34.

[71] Ryckmans Y, André N. Novel Certification Procedure For The Sustainable Import Of Wood Pellets To Power Plants In Belgium. http://www.laborelec.be/ENG/wpcontent/uploads/PDF/Ryckmans-OC6_4-Marketsustainability.pdf ; 2003. [accessed 21.08.15].

[72] Infobio, 2014b. Information and Analyticl Agancy “Infobio”. Аналитики иаа«инфобио» выявили интересные факты, связанные с экспортом древесных топливных гранул: чрезмерно завышенные цены на пеллеты. (IAA "infobio" find out interesting facts related to the export of wood pellets: extremely high prices for pellets); [In Russian]. http://www.infobio.ru/news/2693.html ; 2014 [accessed 18.09.14].

[73] Infobio, 2014c. Information and Analyticl Agancy "Infobio". Разработчиком индекса цен на топливные гранулы промышленного качества стало ИАА «ИНФОБИО». (Тhe developer of the price index for industrial wood pellets quality became IAA "INFOBIO"); [In Russian]. http://www.infobio.ru/news/2690.html ; 2014 [accessed 18.10.14].

[74] Cocchi M, Nicolaisen L, Junginger M, Gog CS, Heinimö J, Bradley D, et al. Global wood pellet industry market and trade study. IEA Bioenergy Task 40: Sustainable International Bioenergy Trade, http://bioenergytrade.org/downloads/t40-global-wood-pellet-marketstudy_final_R.pdf ; 2011 [accessed 20.03.14].

[75] McBride AC, Dale VH, Baskaran LM, Downing ME, Eaton LM, Efroymson RA, et al. Indicators to support environmental sustainability of bioenergy systems. Ecological Indicators 2011;11(5):1277-89.

[76] Sikkema R, Junginger M, Pichler W, Hayes S, Faaij APC. The international logistics of wood pellets for heating and power production in Europe: costs, energy-input and greenhouse gas balances of pellet consumption in Italy, Sweden and the Netherlands. Biofuels Bioprod Biorefin 2010;4(2):132-53.

[77] Hansson J, Martinsson F, Gustavsson M. Greenhouse gas performance of heat and electricity from wood pellet value chains - based on pellets for the Swedish market. Biofuels Bioprod Biorefin 2015;9(4): 378-96.

[78] Directive 2012/33/EU of the European Parliament and of the Council of 21 November 2012 amending Council Directive 1999/32/EC as regards the sulphur content of marine fuels.

[79] HELCOM. About us. http://www.helcom.fi/about-us ; 2015. [accessed 21.08.15].

[80] HELCOM. Sustainable Baltic Sea Shipping Green Technology and Alternative Fuels Draft Roadmap for future actions 2014 - 2016 and 2017 - 2025 Shaping the future together. http://www.helcom.fi/Documents/HELCOM\%20at\%20work/Meetings/Events/Green\%20tec hnology\%20and\%20alternative\%20fuels/14042014\%20Roadmap\%20Baltic\%20Sea\%20Sus 
tainable\%20Shipping_EN.pdf ; 2014. [accessed 21.08.15].

[81] Duca D, Riva G, Pedretti EF, Toscano G. Wood pellet quality with respect to EN 14961-2 standard and certifications. Fuel 2014;135:9-14.

[82] García-Maraver A, Popov V, Zamorano M. A review of European standards for pellet quality. Renewable Energy 2011;36:3537-40.

[83] Azeus Biopellet Machines. DIN plus pellets or EN plus pellets, http://www.biopelletmachine.com/biopellets-making-guidance/wood-pellet-certificationstandard.html [accessed 08.03.15].

[84] European Pellet Council. Handbook for the Certification of Wood Pellets for Heating Purposes. In: AEBIOM-European Biomass Association. Version 2.0. Brussels, Belgium. http://www.enplus-pellets.eu/ ; 2013 [accessed 18.08.15].

[85] USDA (U.S. International Pellet Association). EU Biofuels Annual 2013. Foreign Agricultural Service. GAIN Report No.NL3034; 2013.

[86] Alakangas E. Suomessa käytettävien polttoaineiden ominaisuuksia [e-document]. (The features of fuels use in Finland). VTT Technical Research Centre of Finland; [In Finnish], http://www.vtt.fi/inf/pdf/tiedotteet/2000/T2045.pdf ; 2000 [accessed 20.03.15].

[87] ISO, 2014a. ISO/DIS 13065. Sustainability criteria for bioenergy [webpage]. http://www.iso.org/iso/home/store/catalogue tc/catalogue_detail.htm?csnumber=52528 ; 2014 [accessed 18.10.14].

[88] Biomass Magazine. Forest Certification: Opportunity and Challenge for the Wood Pellet Industry, http://biomassmagazine.com/articles/6258/forest-certification-opportunity-andchallenge-for-the-wood-pellet-industry ; 2012 [accessed 18.08.14].

[89] Muiste M, Habicht M. Pellet market country report Baltic countries ESTONIA / LATVIA / LITHUANIA [e-document]. Pellets Atlas project. http://www.pelletsatlas.info/pelletsatlas_docs/showdoc.asp?id=091022144807\&pdf=true ; 2009 [accessed 18.03.15].

[90] Gamborg C, Anker HT, Sandøe P. Ethical and legal challenges in bioenergy governance: Coping with value disagreement and regulatory complexity. Energy Policy 2014;69:326-33.

[91] ENDS Europe. Biomass criteria ditched, Commission confirms [webpage]. Updated 12 May 2014. Available only for subscribers. http://www.endseurope.com/35799/biomass-criteriaditched-commission-confirms? referrer=search ; 2014 [accessed 20.03.15].

[92] Directive 2009/28/EC of the European Parliament and of the Council 23 April 2009 on the promotion of the use of energy from renewable sources and amending and subsequently repealing Directives 2001/77/EC and 2003/30/EC (Text with EEA relevance).

[93] COM (2010)11 final. Report from the Commission to the Council and the European Parliament on sustainability requirements for the use of solid and gaseous biomass sources in electricity, heating and cooling. 2010.

[94] SWD (Staff Working Document). 259 final Commission SWD: State of play on the sustainability of solid and gaseous biomass used for electricity, heating and cooling in the EU. 2014.

[95] Goldthau A, Boersma T. The 2014 Ukraine-Russia crisis: Implications for energy markets and scholarship. Energy Research \& Social Science 2014;3:13-15.

[96] Wood pellet association of Canada. Canadian Biomass.Canadian Wood Pellets - An Industry on the Move. In: CANBIO Annual Conference \& Trade Show, Vancouver, BC; 2012.

[97] Office of industries working paper U.S. International Trade Commission. Developments in 
the global trade of wood pellets, 2015 http://www.usitc.gov/publications/332/wood_pellets_id-039_final.pdf [accessed 15.09.15]. 